\title{
ANALISIS PROSPEKTIF USAHA ABON IKAN (KASUS: CV AROMA FOOD KOTA BANDA ACEH)
}

\author{
PROSPECTIVE ANALYSIS OF FISH FLOSS BUSINESS \\ (CASE: CV AROMA FOOD KOTA BANDA ACEH)
}

\author{
Uyunun $^{1,2}$, Ernik Yuliana ${ }^{2 *}$, Mala Nurilmala ${ }^{3}$ \\ ${ }^{1}$ UPTD Laboratorium Pembinaan dan Pengujian Mutu Hasil Perikanan (LPPMHP) Aceh, Jalan Tengku \\ Abdul Rahman No.7, Kuta Alam, Kec. Kuta Alam, Kota Banda Aceh, Aceh 24415 \\ ${ }^{2}$ Program Magister Manajemen Perikanan, Program Pascasarjana, Universitas Terbuka, Jalan Cabe \\ Raya, Pondok Cabe, Pamulang, Tangerang Selatan, Banten 15418 \\ ${ }^{3}$ Departemen Teknologi Hasil Perikanan, Fakultas Perikanan dan Ilmu Kelautan, IPB University, Jl. Raya \\ Dramaga, Babakan, Kec. Dramaga, Bogor, Jawa Barat 16680
}

Teregistrasi I tanggal: 21 Agustus 2020; Diterima setelah perbaikan tanggal: 15 September 2020; Disetujui terbit tanggal: 21 September 2020

\begin{abstract}
ABSTRAK
Ikan merupakan salah satu bahan pangan yang diperlukan oleh tubuh manusia karena memiliki kandungan gizi yang tinggi. Salah satu upaya untuk mempertahankan mutu ikan tuna dan memperpanjang daya simpannya adalah dengan mengolahnya menjadi abon ikan. Penelitian ini bertujuan untuk menganalisis penerapan Good Manufacturing Practices (GMP) dan aspek finansial usaha pengolahan abon ikan. Penelitian ini menggunakan metode survei, berlokasi di CV Aroma Food, Banda Aceh. Pengumpulan data dilakukan dengan wawancara dan observasi. Analisis data dilakukan secara deskriptif. Hasil penelitian menunjukkan bahwa CV Aroma Food sudah melakukan penerapan Good Manufacturing Practices (GMP) dan Sanitation Standard Operating Procedures (SSOP) pada pengolahan abon ikan. Ditinjau dari analisis finansial usaha, CV Aroma Food layak untuk dijalankan, karena usaha tersebut menghasilkan keuntungan yang signifikan (mempunyai nilai benefit cost ratio 1,55). Kandungan kadar protein abon ikan sebesar $31,14 \%$ serta kandungan air sebesar 29,76\%. Bakteri Escherichia coli yang ditemukan pada abon ikan < $3 \mathrm{APM} / \mathrm{g}$ dan angka lempeng total 2,0 x $104 \mathrm{koloni} / \mathrm{g}$. Uji sensori memperoleh nilai 9. Secara umum, CV Aroma Food sudah menerapkan GMP dengan baik, dan usaha layak dilanjutkan.
\end{abstract}

Kata kunci: abon ikan, GMP, ikan tuna, sensori

\begin{abstract}
Fish is one of the food needed by human body because it has a high nutritional content. One of the efforts to maintain the quality of the tuna fish and extend its shelf life is to process it into fish floss. This study aims to analyze the application of Good Manufacturing Practices (GMP) and the financial aspects of the fish floss processing business. This study used a survey method, located at CV Aroma Food, Banda Aceh. Data collection was carried out by interview and observation. Data analysis was done descriptively. The results indicated that CV Aroma Food has implemented Good Manufacturing Practices (GMP) and Sanitation Standard Operating Procedures (SSOP) in fish floss processing. Judging from the business financial analysis, CV Aroma is feasible to run due to significant profits gained (it has a benefit cost ratio value of 1.55).
\end{abstract}

Korespondensi penulis:

*Email: ernik@ecampus.ut.ac.id

DOI: http://dx.doi.org/10.15578/plgc.v1i3.9288 
Protein content of fish floss $31.14 \%$, water content $29.76 \%$. Escherichia coli bacteria found in fish floss $<3 \mathrm{APM} / \mathrm{g}$ and total plate counts $2.0 \times 104$ colonies $/ g$. The sensory test obtained a score of 9. In general, CV Aroma Food has implemented GMP well, and efforts are worth continuing.

Keywords: GMP, fish floss, sensory, tuna fish

\section{PENDAHULUAN}

Ikan merupakan salah satu bahan pangan yang diperlukan oleh tubuh manusia. Ikan memiliki kandungan air $72,2 \%$, protein $21,3 \%$, abu $2,14 \%$, lemak $0,38 \%$ dan karbohidrat 3,97\% (Deni et al., 2013). Sesuai dengan salah satu program pemerintah yaitu membantu meningkatkan kebutuhan protein dengan mengkampanyekan gemar makan ikan, maka perlu dilakukan usaha diversifikasi hasil perikanan dalam bentuk produk olahan (Restu, 2016). Diversifikasi pangan merupakan alternatif untuk meningkatkan daya serap pasar, atau dengan kata lain meningkatkan permintaan serta menciptakan upaya lebih banyak bagi para pengolah hasil perikanan untuk mengembangkan usahanya (Agustini \& Swastawati, 2003).

Secara umum hasil perikanan cepat mengalami kemunduran mutu jika dibandingkan dengan bahan makanan lain. Kemunduran mutu pada ikan tersebut disebabkan oleh adanya bakteri pembusuk dan terjadi perubahan kimiawi pada ikan yang mati sehingga menyebabkan pembusukan (Kusumayanti et al., 2011). Salah satu upaya yang dilakukan untuk mempertahankan mutu ikan dan memperpanjang daya simpannya adalah dengan pengolahan ikan menjadi abon ikan. Ikan tuna sirip kuning (Thunnus albacares) adalah salah satu jenis ikan yang dapat dijadikan sebagai bahan baku pembuatan abon ikan karena tingginya jumlah tangkapan dan memiliki kandungan gizi yang tinggi. Berdasarkan data dari DKP Aceh (2017), jumlah produksi ikan tuna sirip kuning yang didaratkan di Pelabuhan Perikanan
Lampulo Banda Aceh mengalami peningkatan dari 2.119 ton menjadi 2.459 ton pada tahun 2016. Analisis yang dilakukan oleh Peng et al., (2013) melaporkan bahwa ikan tuna sirip kuning mengandung kadar air $73,57 \%$, protein kasar $23,52 \%$, lemak kasar $1,93 \%$ dan kadar abu $1,54 \%$. Ikan tuna juga mengandung asam amino esensial yang tinggi diantaranya isoleusin $4,06 \%$, leusin $6,99 \%$, lisin $8,19 \%$, methionine $2,55 \%$, tyrosin $3,19 \%$, treonin $3,85 \%$, tryptophan $0,88 \%$, valin $4,54 \%$ dan histidin 5,49\% berdasarkan berat kering.

Kegiatan usaha yang dilakukan oleh pengolah hasil perikanan senantiasa harus memenuhi standar keamanan pangan serta memberikan kepuasan bagi konsumen. Persyaratan kelayakan dasar keamanan pangan tidak terlepas dari Good Manufacturing Practices (GMP) dan Sanitation Standard Operating Procedures (SSOP). Prinsip dasar GMP adalah menjamin kualitas mutu yang baik dengan cara membuat produk dengan prosedur tertentu, mulai dari proses penerimaan bahan baku sampai produk akhir Sanitation Standard Operating Procedures (SSOP) yang merupakan alat bantu dalam penerapan Good Manufacturing Practices (GMP). Program ini bertujuan untuk mencegah terjadinya kontaminasi secara langsung terhadap produk yang dihasilkan dan meningkatkan kualitas serta menjamin produk agar aman untuk dikonsumsi.

Salah satu usaha yang bergerak dalam bidang produk olahan abon ikan adalah CV Aroma Food yang merupakan salah satu usaha kecil dan menengah (UKM) di Kota Banda Aceh. CV Aroma Food ini sudah memiliki Sertifikasi Kelayakan Pengolahan (SKP) dengan 
nomor 6924/11/SKP/LN/VIII/2017 yang memproduksi abon ikan. Abon ikan adalah jenis makanan awetan yang terbuat dari ikan yang diberi bumbu, diolah dengan cara perebusan dan penggorengan. Produk yang dihasilkan mempunyai bentuk lembut, rasa enak, bau khas dan mempunyai daya awet yang relatif lama, yaitu 15 hari pada suhu kamar (Dewi et al., 2011). Seiring berjalannya waktu, pelaku bisnis melihat adanya prospek dan potensi pasar yang baik dalam menjalankan bisnis di bidang produk abon ikan, namun dalam memulai suatu usaha perlu dipertimbangkan segala aspek mendasar dalam memulai suatu usaha, sehingga usaha yang dijalankan dapat mencapai keuntungan secara finansial. Hal lain yang penting adalah keamanan pangan. Untuk mendapatkan mutu berkualitas tinggi, pengawasan

\section{BAHAN DAN METODE}

Waktu dan Tempat

Penelitian dilaksanakan dalam dua tahap, tahap pertama tanggal 10 Januari sampai dengan 10 Februari 2017 yang bertempat di CV Aroma Food Kota Banda Aceh dan dengan menguji kandungan gizi meliputi kadar protein dan kadar air di Laboratorium Balai Riset dan Standardisasi (Baristand) Industri Banda Aceh.

\section{Pengumpulan Data}

Metode pengumpulan data menggunakan teknik wawancara, observasi, dan dokumentasi. Narasumber yang diwawancarai di CV Aroma Food yaitu Direktris sekaligus pemilik perusahaan (1 orang), bagian keuangan (2 orang), bagian produksi ( 2 orang), bagian administrasi dan pemasaran (marketing) (2 orang) serta masyarakat setempat sebanyak 34 responden. Peneliti menggunakan panduan wawancara (interview guide) yang bertujuan agar fokus wawancara tidak keluar dari konteks penelitian. Alat wawancara yang keamanan pangan perlu dilakukan sehingga produk abon yang dihasilkan dapat bersaing di pasaran.

Penelitian ini bertujuan untuk menganalisis penerapan Good Manufacturing Practices (GMP) dan menganalisis aspek finansial usaha $\mathrm{CV}$ Aroma Food Kota Banda Aceh dengan indikator finansial seperti keuntungan, Benefit Cost Ratio, Break Event Point, dan Payback Period, kandungan gizi abon ikan, aspek mikrobiologi seperti bakteri Escherichia. coli dan jumlah bakteri total sebagai indikator mutu pada produk olahan abon ikan, aspek organoleptik terhadap produk olahan abon ikan dengan indikator kenampakan, bau, rasa dan tekstur serta aspek sosial dan lingkungan terhadap masyarakat di sekitar CV Aroma Food Banda Aceh.

digunakan dalam pengambilan data pada penelitian ini adalah: (1) panduan wawancara, (2) catatan lapangan, (3) alatalat tulis, serta (4) recorder, dan (5) kamera. Pengumpulan data juga dilakukan dengan observasi terhadap fenomenafenomena yang tampak pada objek-objek penelitian di lapangan. Observasi yang dilakukan berfokus pada penerapan Good Manufacturing Practices (GMP) dan Sanitation Standard Operating Procedures (SSOP) berdasarkan Peraturan Menteri Perindustrian Republik Indonesia No. 75/M-IND/PER/7/2010 tentang Pedoman Cara Produksi Pangan Olahan yang Baik (CPPOB) atau Good Manufacturing Practices (GMP).

\section{Pengujian Produk Abon Ikan}

Pengujian produk abon ikan meliputi analisis proksimat (kadar air, lemak, dan protein), uji organoleptik, dan uji mikrobiologi. Uji organoleptik dan mikrobiologi dilakukan di UPTD Laboratorium Pembinaan dan Pengujian Mutu Hasil Perikanan (LPPMHP) Banda Aceh dengan panelis terlatih berjumlah delapan orang. Lembar penilaian (score 
sheet) pada uji organoleptik meliputi penilaian terhadap penampakan, bau, rasa dan tekstur dari abon ikan dengan range nilai 1 - 9 (SNI 7690.1:2013).

Tahap kedua pengujian adalah menguji kandungan gizi berupa kadar lemak bertempat di Laboratorium Balai Riset dan Standardisasi (Baristand) Industri Banda Aceh. Kadar lemak merupakan indikator yang kritis pada abon ikan, karena penyebab bau tengik jika terjadi reaksi oksidasi, sehingga uji lanjut difokuskan pada kadar lemak.

\section{Analisis Data}

Analisis data secara umum dilakukan secara deskriptif. Analisis finansial terdiri atas aspek berikut ini:

1) Analisis Keuntungan

Analisis keuntungan yaitu dengan menghitung selisih antara penerimaan dengan biaya yang digunakan. Analisis keuntungan dihitung menggunakan rumus sebagai berikut:

Keuntungan $=\mathrm{TR}-(\mathrm{TFC}+\mathrm{TVC})$

Keterangan:

TR = Total Penerimaan (Rp)

TFC = Total Biaya Tetap (Rp)

TVC = Total Biaya Variabel $(\mathrm{Rp})$

2) Benefit Cost Ratio (B/C Ratio)

B/C Ratio dihitung menggunakan rumus sebagai berikut:

$\mathrm{B} / \mathrm{C}$ Ratio $=($ Total Penerimaan $) /($ Total Biaya Tetap + Total Biaya Variabel)

Suatu usaha disebut layak bila B/C lebih besar dari $1(\mathrm{~B} / \mathrm{C}>1)$. Semakin tinggi nilai $\mathrm{B} / \mathrm{C}$ maka tingkat keuntungan yang diperoleh pun akan semakin tinggi.

3) Titik Impas atau Break Event Point (BEP)

Analisis BEP merupakan alat analisis untuk mengetahui batas nilai produksi atau volume produksi suatu usaha mencapai titik impas (tidak untung dan tidak rugi).

BEP Produksi $=\mathrm{TC} /($ Harga Penjualan $)$

BEP Harga $=\mathrm{TC} /($ Total Produksi $)$
Keterangan:

$\mathrm{BEP}$ produksi $=$ break event point produksi (gram)

BEP harga = break event point harga (Rp/gram)

TC $=$ total cost $(\mathrm{Rp})$

4) Pay Back Period (PBP)

Analisis PBP adalah analisis perbandingan usaha perlu ditampilkan untuk mengetahui berapa lama usaha yang dikerjakan baru dapat mengembalikan investasi.

$\mathrm{PBP}=($ Total Investasi $) /$ Keuntungan $\mathrm{x} 1$ tahun

Keterangan:

PBP = pay back period (Tahun)

5) Analisis proksimat

Kandungan gizi yang diamati meliputi kadar protein, kadar lemak dan kadar air yang dilakukan pada laboratorium Baristand Banda Aceh. Jumlah sampel adalah lima, diambil secara acak dari kemasan abon ikan seberat $100 \mathrm{~g}$ yang siap dipasarkan, dengan varian rasa yang sama. Analisis proksimat dilakukan dengan tiga kali ulangan. Kadar Protein dianalisis menggunakan metode Kjeldahl (Takeuchi, 1988), pengukuran kadar lemak pada abon ikan dilakukan menggunakan metode Soxhlet (SNI 012891-1992). Kadar air dianalisis menggunakan metode gravimetri (Takeuchi, 1988).

6) Analisis mikrobiologi

Uji mikrobiologi sama halnya dengan analisis proksimat menggunakan lima sampel dan tiga kali ulangan. Uji mikrobiologi yang dilakukan meliputi uji Angka Lempeng Total (ALT) dan Escherichia coli. Pengujian ALT dilakukan dengan metode uji (SNI 012332-3:2015) dan pengujian $E$. coli untuk menentukan bakteri indikator sanitasi (coliform dan E. coli) pada produk perikanan. Pengujian E. coli mengacu pada (BSN, 2006). Satuan untuk hasil uji E. coli adalah dalam angka paling memungkinkan (APM)/g. 
7) Analisis dampak sosial

Analisis aspek sosial dan lingkungan dilakukan secara deskriptif untuk mengetahui dampak yang diberikan atau diterima oleh masyarakat setempat mengenai suatu kegiatan usaha.

\section{HASIL DAN BAHASAN HASIL}

\section{Penerapan GMP dan SSOP}

Hasil observasi melalui wawancara tentang penerapan GMP dan SSOP di CV Aroma Food disajikan pada Tabel 1.

Berdasarkan penjelasan pada Tabel 1, menunjukkan bahwa CV Aroma Food Kota Banda Aceh sudah menerapkan GMP dan SSOP sesuai dengan standar kelayakan pengolahan.

\section{Aspek Finansial}

Analisis finansial usaha abon ikan di CV Aroma Food Kota Banda Aceh didasarkan pada data dalam satu kali produksi. Dalam sebulan, produksi abon ikan dilakukan sebanyak 10 kali. Hasil analisis finansial disajikan pada Tabel 2.

Berdasarkan data pada Tabel 2, biaya investasi yang dikeluarkan oleh $\mathrm{CV}$ Aroma Food Kota Banda Aceh untuk membuat produk olahan abon ikan sebesar Rp10.560.000,00. Biaya ini digunakan sebagai awal dalam menjalankan usaha abon ikan tuna hingga mencapai target usia ekonomi, meliputi biaya pembelian alat-alat dan biaya penyusutan. Biaya tetap ini meliputi biaya listrik, telepon, gaji karyawan, dan kemasan. Total biaya tetap yang dikeluarkan oleh CV Aroma Food yang telah dibagi masa pakai sebesar Rp182.100,00 dalam sekali produksi. Dalam sebulan biaya tetap yang dikeluarkan mencapai Rp 1.821.000,00 karena 10 kali produksi.

Berdasarkan perhitungan nilai BCR, maka diperoleh nilai sebesar 1,55 . Nilai tersebut berarti bahwa usaha CV Aroma Food memperoleh keuntungan dalam melakukan produksi abon. Nilai BCR sebesar 1,55 mempunyai arti bahwa setiap biaya produksi yang dikeluakan sebesar Rp1.000,00 maka akan diperoleh penerimaan sebesar Rp1.550,00. Hasil perhitungan tersebut sesuai dengan pernyataan Effendi \& Oktariza (2006) yang menyatakan bahwa suatu usaha dikatakan layak apabila BCR lebih besar dari 1 (BCR > 1). Oleh sebab itu, usaha abon ikan tuna di CV Aroma Food Kota Banda Aceh layak untuk dikembangkan karena nilai Net BCR > 1.

Berdasarkan hasil perhitungan diperoleh nilai PBP sebesar 5,6 bulan yang diperoleh perbandingan antara nilai investasi sebesar Rp10.560.000,00 dengan keuntungan per bulan sebesar Rp1.875.000,00 dikalikan dengan umur investasi selama 1 tahun. Nilai PBP menunjukkan bahwa usaha produk abon ikan tuna yang di produksi oleh CV Aroma Food Kota Banda Aceh akan mengalami pengembalian modal pada 5,6 bulan atau 5 bulan 6 hari.

\section{Uji Mikrobiologi}

Hasil pengujian ALT pada abon ikan adalah 2,0 x 104 koloni/g. Berdasarkan hasil analisis E. coli didapatkan hasil $<3$ APM/g. Hal ini menunjukkan bahwa nilai tersebut sesuai dengan acuan Standar Nasional Indonesia (SNI 7690.1:2013) yaitu maksimal kandungan bakteri E. coli dalam suatu produk adalah < 3 APM/g.

\section{Uji Organoleptik}

Hasil pengujian organoleptik
berdasarkan perhitungan terhadap penilaian sensori penampakan, bau, rasa dan tekstur, masing-masing di peroleh nilai 9, memenuhi persyaratan standar persyaratan mutu dan keamanan pangan berdasarkan SNI 7690.1:2013 yaitu dengan nilai minimal 7. Produk abon ikan memiliki penampakan warna coklat spesifik jenis (kuning kecoklatan), serat homogen, sangat cemerlang. Bau spesifik abon ikan sangat kuat, rasa spesifik abon ikan sangat terasa, tekstur kering, tidak menggumpal. 
Tabel 1. Aspek-aspek GMP dan SSOP serta penerapannya di CV Aroma Food Table 1. GMP and SSOP aspects and their implementation at CV Aroma Food

\begin{tabular}{ll}
\hline Aspek GMP dan SSOP & Kondisi CV Aroma Food Kota Banda Aceh \\
\hline Lingkungan dan sarana & $\begin{array}{l}\text { Lingkungan CV Aroma Food berada pada lingkungan pelabuhan Ulee } \\
\text { produksi } \\
\text { Lheue kota Banda Aceh, dan sarana produksi yang lengkap untuk } \\
\text { produksi abon ikan. }\end{array}$ \\
Peralatan pengolahan & $\begin{array}{l}\text { Peralatan dalam keadaan bersih dan terawat dan terbuat dari bahan } \\
\text { yang tidak membahayakan kesehatan. Sebelum digunakan, peralatan } \\
\text { dicuci bersih dan dipastikan tidak ada benda asing yang berbahaya. }\end{array}$ \\
Karyawan dalam kondisi sehat, tidak memiliki luka, maupun penyakit \\
kulit.
\end{tabular}

Tabel 2. Analisis keuntungan abon ikan di CV Aroma Food per produksi Table 2. Financial analysis of fish floss at CV Aroma Food in one production

\begin{tabular}{lr}
\hline \multicolumn{1}{c}{ Kriteria } & Hasil (Rp) \\
\hline Biaya Investasi & $10.560 .000,00$ \\
Biaya Tetap & $182.100,00$ \\
Biaya Variabel & $158.400,00$ \\
Total Biaya (tetap + variabel) & $340.500,00$ \\
Penerimaan & $528.000,00$ \\
Keuntungan & $187.500,00$ \\
B/C Ratio & 1,55 \\
BEP Harga & $22.000,00$ \\
Pay Back Period & 5,60 \\
\hline
\end{tabular}

\section{Kandungan Gizi}

1) Kadar Protein

Hasil pengamatan kadar protein abon ikan tuna di CV Aroma Food Kota
Banda Aceh ditemukan sebesar 31,14\%. Kadar protein pada abon ikan tuna ini lebih tinggi dibandingkan dengan kadar protein abon ikan gabus (Ophiocephalus 
striatus) hasil penelitian Sulthoniyah et al, (2013) yaitu $8,51 \%$ dan abon ikan gabus yang disubtitusi sukun sebesar 19,8\% (Dara \& Arlinda, 2017). Namun kadar protein abon pada CV Aroma Food lebih rendah dibandingkan dengan hasil penelitian Sahara et al. (2018) pada abon ikan cakalang dari hasil pengawetan berbeda sebesar $36,21 \%$ dan protein abon ikan karandang dengan penambahan kelapa parut sebesar 43,1\% (Restu, 2016). Namun demikian, kadar protein abon ikan tuna ini tersebut sudah memenuhi persyaratan SNI 7690.1:2013 yaitu dengan kandungan protein minimal 30\%.

\section{2) Kadar Lemak}

Berdasarkan hasil pengamatan menunjukkan bahwa nilai kadar lemak yang diperoleh pada produk abon ikan tuna sebesar 2,49\%. Kadar lemak abon ikan tuna yang diperoleh lebih tinggi dibandingkan dengan kadar lemak pada abon ikan gabus yaitu 1,97\% (Sulthoniyah et al., 2013). Namun, kadar lemak ini lebih rendah dibandingkan dengan kadar lemak abon ikan karandang yaitu 17,1\% (Restu, 2016) dan kadar lemak pada abon ikan cakalang dari proses pengawetan yang berbeda yaitu $21,17 \%$ (Sahara et al., 2018). Berdasarkan SNI 01-3707-1995 bahwa kadar lemak abon ikan maksimal $30 \%$. Lemak merupakan zat makanan penting yang sangat diperlukan tubuh sebagai sumber energi. Disamping itu, kandungan kadar lemak ditemukan hampir pada semua bahan pangan dengan kosentrasi berbeda-beda.

Kandungan kadar lemak pada abon ikan tuna CV Aroma Food jauh lebih rendah dibandingkan dengan beberapa penelitian lainnya. Hal ini disebabkan oleh banyaknya kadar air yang ditemukan pada produk tersebut. Rahayu et al., (1992) menyatakan bahwa kandungan kadar lemak pada ikan berbanding terbalik dengan jumlah kadar air. Ikan yang mempunyai kandungan lemak tinggi umumnya memiliki kandungan air cenderung lebih rendah (Riansyah et al., 2013). Hal ini didukung oleh penelitian
Zuhra et al., (2012) yang menyatakan bahwa meningkatnya kandungan lemak dengan suhu pengeringan yang tinggi dapat disebabkan oleh penurunan kandungan air sehingga presentase kandungan lemak dalam produk olahan meningkat.

\section{3) Kadar Air}

Hasil pengujian kadar air yang ditemukan pada produk olahan abon ikan pada CV Aroma Food Kota Banda Aceh sebesar 29,76\%. Kadar air ini lebih tinggi dibandingkan dengan kandungan kadar air pada abon ikan karandang yaitu 10,3\% (Restu, 2016), kadar air pada abon ikan cakalang yaitu 2,40\% (Sahara et al., 2018) dan kandungan air pada abon ikan gabus yaitu 5,32\% (Sulthoniyah et al., 2013) serta kandungan air pada abon ikan gabus yang disubtitusi sukun yaitu 14,8\% (Dara \& Arlinda, 2017) Berdasarkan SNI 7690.1:2013 kandungan air yang dipersyaratkan dalam abon ikan maksimal $15 \%$.

\section{Aspek Sosial dan Lingkungan}

Hasil analisis terhadap aspek sosial dan lingkungan pada CV Aroma Food Kota Banda Aceh disajikan pada Gambar 1.

Berdasarkan hasil analisis aspek sosial dan lingkungan (Gambar 1) menunjukkan bahwa usaha abon ikan tuna pada CV Aroma Food Kota Banda Aceh memberikan dampak positif, baik terhadap pengusaha maupun masyarakat sekitar. Bagi pengusaha itu sendiri, abon ikan tuna dapat meningkatkan pendapat karena usaha abon ikan tuna ini merupakan peluang bisnis yang menguntungkan. Selain itu, dengan beroperasinya usaha abon ikan akan membantu penyerapan tenaga kerja bagi masyarakat sekitar sehingga dapat membantu peningkatan pendapatan dan kesejahteraan masyarakat. Dampak lingkungan terhadap masyarakat sekitar berkaitan dengan analisis potensi limbah yang dihasilkan dari kegiatan produksi. 


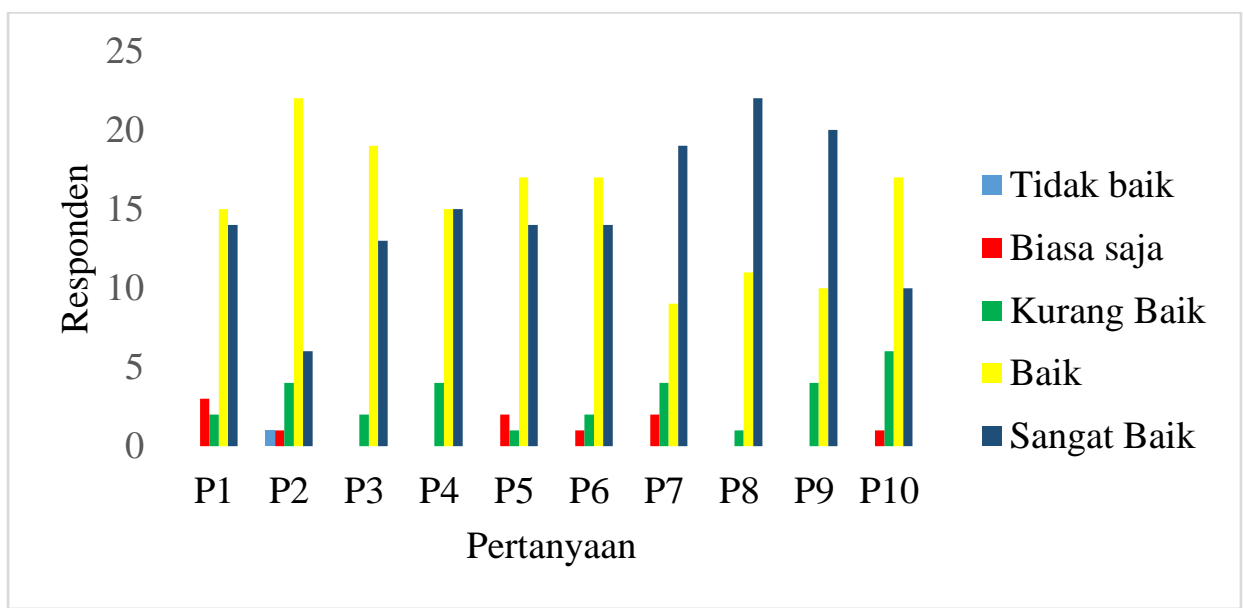

Gambar 1. Hasil analisis aspek sosial dan lingkungan (Keterangan: P1 = penyediaan fasilitas sosial; P2 = keterlibatan masyarakat; P3 = masyarakat pendatang; P4 = manfaat keberadaan CV Aroma Food; P5 = peran CV Aroma Food di masyarakat; P6 = hubungan CV Aroma Food dengan masyarakat; P7 = peningkatan ekonomi masyarakat; $\mathrm{P} 8$ = masa depan $\mathrm{CV}$ Aroma Food; $\mathrm{P} 9$ = pandangan umum masyarakat; $\mathrm{P} 10=$ dampak sosial dan lingkungan)

Figure 1. Analysis results of social and environmental aspect (Information: $P 1=$ provision of social facilities; $P 2$ = community involvement; $P 3=$ immigrant community; P4 = benefits of CV Aroma Food; $P 5=$ role of $C V$ Aroma Food in society; P6 = relationship between CV Aroma Food and society; P7 =

improvement of community economy ; $P 8=$ future of $C V$ Aroma Food; $P 9=$ general opinion from society; $P 10=$ social and environmental impacts)

\section{BAHASAN}

CV Aroma Food yang memproduksi abon ikan tuna telah menerapkan GMP dalam proses produksinya. Penerapan GMP dalam suatu industri makanan sangat penting, karena akan menjadi jaminan bahwa produk industri tersebut layak dan amakn dikonsumsi.

Abon ikan di CV Aroma Food mempunyai nilai ALT yang rendah $(2,0 \mathrm{x}$ 104 koloni/g), karena bahan baku ikan tuna dalam kondisi segar sehingga tidak terjadi kontaminasi ketika pengolahan produk abon ikan. Selain itu, sanitasi dan hygiene benar-benar diperhatikan sehingga produk abon yang diproduksi memiliki kualitas yang baik. Dengan demikian, abon ikan tuna pada CV Aroma Food Kota Banda Aceh layak dikonsumsi sesuai dengan ketentuan persyaratan mutu dan keamanan pangan Standar Nasional Indonesia. Persyaratan Angka Lempeng Total (ALT) berdasarkan SNI 7690.1:2013 menyatakan bahwa persyaratan Angka Lempeng Total (ALT) untuk abon ikan adalah tidak melebihi dari 5 x 104 koloni $/ g$ atau 50.000 koloni $/ g$.

Hasil uji ALT lebih rendah dibandingkan dengan hasil uji ALT pada abon ikan tuna pada Balai Besar Pengawas Obat dan Makanan (BBPOM) Yogyakarta dengan hasil uji sebesar 4,0 x 105 koloni/g (Nugraheni, 2010). Hasil pengujian ALT tersebut berada di bawah standar maksimal persyaratan mutu (SNI 012332-3:2015) dan keamanan pangan abon ikan yang diperbolehkan dalam suatu produk, sehingga abon ikan CV Aroma Food aman di konsumsi.

Hasil pengujian E. coli abon ikan tuna pada CV Aroma Food yang didapat masih di bawah standar persyaratan mutu dan keamanan pangan abon ikan yang diperbolehkan dalam suatu produk oleh karenanya abon ikan CV Aroma Food aman di konsumsi. Standar sanitasi bahan makanan baik makanan segar maupun olahan yang berasal dari ikan seperti abon ikan harus terbebas dari cemaran bakteri coliform dan E. coli. Bakteri E. coli merupakan anggota flora normal usus 
yang berperan dalam mensintesa vitamin $\mathrm{K}$, konversi pigmen-pigmen empedu, asam-asam empedu dan penyerapan zatzat makanan (Suardana et al., 2016). Bakteri E. coli termasuk jenis bakteri heterotrof yang mendapatkan makanan dari lingkungannya karena tidak dapat mensintesa makanan sendiri (Kabiru et al., 2015). Bakteri E. coli menjadi patogen apabila jumlahnya dalam saluran pencernaan meningkat atau berada diluar usus, karena bakteri E. coli menghasilkan toksin yang dikenal dengan enterotoksin yang menyebabkan beberapa kasus diare.

Berdasarkan hasil uji organoleptik, abon ikan CV Aroma Food memenuhi standar persyaratan mutu. Warna atau penampakan merupakan parameter organoleptik yang paling utama dalam penyajian. Warna ini menentukan persepsi konsumen terhadap suatu bahan pangan. Warna pada produk pangan mempunyai beberapa fungsi antara lain sebagai indikator kematangan terutama pada produk pangan segar dan sebagai indikator kesempurnaan proses pengolahan pangan dan indikator akhir kematangan produk pangan (Sahara et.al., 2018; Maskur, 2018; Fajriyati, 2012). Aroma atau bau sangat menentukan tingkat penerimaan panelis dari suatu produk. Aroma akan meningkatkan selera konsumen, aroma tersebut ditangkap oleh indra penciuman melalui saluran yang menghubungkan antara mulut dan hidung.

Rasa merupakan faktor yang menentukan cita rasa makanan. Rasa adalah sesuatu yang diterima oleh lidah dengan cecapan dibagi empat cecapan utama yaitu rasa manis, rasa pahit, rasa asam dan rasa asin serta ada tambahan respon jika dilakukan modifikasi (Zuhra, 2006). Berdasarkan hasil pengamatan uji organoleptik rasa pada abon ikan tuna memiliki nilai 9. Artinya rasa produk abon ikan tuna diterima oleh panelis. Rasa abon ini dipengaruhi oleh cita rasa dari bumbubumbu yang digunakan serta proses pengolahan sehingga menutupi bau amis dari ikan. Menurut Herliani (2008), cita rasa dapat dipengaruhi oleh pemanasan atau pengolahan yang dilakukan sehingga mengakibatkan degradasi penyusun cita rasa dan sifat fisik dari bahan makanan. Pemanasan yang dilakukan pada saat proses pengolahan dapat mempertahankan mutu ikan, perbaikan terhadap cita rasa dan tekstur, nilai gizi serta daya cerna. Selain itu, cita rasa pada abon ikan sangat dipengaruhi oleh bumbu atau rempahrempah yang ditambahkan ketika pengolahan. Penambahan bumbu tersebut dapat menutupi bau atau rasa alami dari ikan. Rasa juga dipengaruhi oleh beberapa faktor lain yaitu senyawa kimia, suhu, konsentrasi dan interaksi dengan komponen rasa yang lain (Winarno, 1997).

Tekstur merupakan salah satu parameter penting dalam pengujian organoleptik yang dirasakan melalui kulit maupun indera pengecap (Mustar, 2013). Hal ini dikarenakan tekstur abon memiliki perbedaan dengan produk perikanan lainnya yaitu memiliki serat-serat yang lembut. Dari hasil pengamatan menunjukkan bahwa tekstur abon ikan tuna dengan nilai 9. Tingginya nilai tersebut diduga bahwa tekstur abon yang diproduksi lembut dan tidak kering karena masih tinggi kandungan air sehingga indera pengecap panelis dapat merasakan teksturnya yang mudah ditelan. Pembuatan abon yang dilakukan dengan proses penyangraian membuat kulit terluar dari bahan akan mengkerut sebagai pengaruh dari dehidrasi selama proses pengeringan berlangsung dan akan membentuk pori-pori dibagian dalam bahan pangan yang ditinggalkan oleh air yang diuapkan. Berdasarkan hasil pengamatan organoleptik pada produk abon ikan tuna dari parameter warna, aroma, rasa dan tekstur, maka dapat disimpulkan bahwa abon tersebut diterima oleh panelis.

Tingginya kadar protein pada produk makanan menjadi pertimbangan tersendiri bagi manusia untuk mengkonsumsi makanan tersebut, karena 
protein merupakan salah satu nutrien yang dibutuhkan oleh tubuh yang berfungsi untuk membangun jaringan tubuh yang rusak serta sebagai zat pengatur tumbuh (Darwis et al., 2015). Selain itu, ikan tuna juga mengandung asam amino essensial. Asam amino ini tidak dapat disintesa oleh tubuh sehingga perlu disuplai dari makanan. Salah satu jenis asam amino esensial yang tinggi pada ikan tuna adalah jenis lysin 8,19\%. Asam amino tersebut berfungsi membantu penyerapan kalsium, pertumbuhan tulang serta pembentukan kolagen.

Hasil pengamatan kandungan air jauh lebih tinggi dibandingkan dengan penelitian lain dan jumlah kandungan air tersebut belum sesuai dengan Standar Nasional Indonesia. Tingginya kandungan air pada produk ini disebabkan oleh proses pengolahan abon dengan cara penyangraian. Kadar air dalam makanan merupakan salah satu indikator persyaratan mutu dan keawetan masa simpan. Semakin rendah kandungan air dalam produk, maka semakin lama daya simpan produk yang dihasilkan karena dapat menghambat aktivitas mikroorganisme. Pengurangan kadar air pada abon ikan tuna ini dapat dikurangi dengan menambah waktu spiner/pengepresan.

Unit kegiatan usaha pengolahan abon ikan tidak menghasilkan limbah berbahaya, baik terhadap masyarakat maupun lingkungan sekitarnya. Limbah yang dihasilkan dari produksi abon ikan tuna hanya air kotor sisa pembersihan. Air tersebut dibuang melalui saluran air yang sudah disediakan. Air tersebut tidak mengandung zat-zat kimia yang membahayakan.

\section{SIMPULAN}

Dari penelitian yang dilakukan pada CV. Aroma Food Kota Banda Aceh dapat disimpulkan bahwa CV Aroma Food Kota Banda Aceh sudah menerapkan Good Manufacturing Practices (GMP) dan
Sanitation Standard Operating Procedures (SSOP) pada pengolahan abon ikan. Ditinjau dari analisis finansial usaha, CV. Aroma Food Kota Banda Aceh layak untuk dijalankan. Produk abon ikan juga mempunyai kandungan gizi yang sesuai dengan standar mutu yang ditetapkan dalam SNI. Hasil uji mikrobilogi juga memenuhi standar mutu yang dipersayaratkan (SNI 7690.1:2013). Uji organoleptik terhadap kenampakan, bau, rasa dan tekstur masing-masing memiliki nilai 9 (sembilan), artinya produk abon ikan pada CV. Aroma Food dapat diterima oleh panelis, dengan demikian dapat juga diterima cita rasanya oleh masyarakat. Aspek sosial dan lingkungan pada produk abon ikan tuna CV. Aroma Food Kota Banda Aceh memberikan dampak positif baik terhadap pemilik usaha maupun masyarakat sekitar.

\section{DAFTAR PUSTAKA}

Agustini, T. W., \& Swastawati, F. (2003). Pemanfaatan Hasil Perikanan sebagai Produk Bernilai Tambah (value-added) dalam Upaya Penganekaragaman Pangan [Utilization of Fishery Products with Added Value to Support Food Diversification]. Jurnal Teknologi dan Industri Pangan, XIV (1), 7481.

Bawole, C. S. F., Mentang, F., \& Dien, H. (2017). Penerapan Pengasapan Cair pada Pengolahan Abon Roa (Hemirhamphus sp.) dan Pampis Cakalang Produk yang Dikemas Modified Atmospheric Packaging (MAP). Jurnal Media Teknologi Hasil Perikanan, 5(1), 102-106.

Dara, W., \& Arlinda. (2017). Mutu Organoleptik dan Kimia Abon Ikan Gabus (Channa striata) yang Disubstitusi Sukun (Artocarpus altilis). Jurnal Katalisator, 2(2), 6166. 
Darwis, D., Edison, N., \& Sari, I. (2015). Studi Penerimaan Konsumen terhadap Abon Ikan Lele Dumbo (Clarias gariepinus) Asap dengan Metode Pengasapan Berbeda. Berkala Perikanan Terubuk, 44(1), 69-78.

Deni, S., Hardjito, L., \& Salamah, E. (2007). Pemanfaatan Daging Ikan Tuna sebagai Kerupuk Kamplang dan Karakterisasi Produk yang Dihasilkan. Jurnal Ilmiah Agribisnis dan Perikanan, 6(2), 6-14.

Dewi, E.N., Ibrahim, R., \& Yuaniva, N. (2011). Daya Simpan Abon Ikan Nila Merah (Oreochromis niloticus Trewavas) yang Diproses dengan Metoda Penggorengan Berbeda. Jurnal Saintek Perikanan, 6(1), 612.

Fajriyati. (2012). Warna Bahan Makanan. Politeknik Negeri Ujung Pandang, Makassar.

Herliani, L. (2008). Teknologi Pengawetan Pangan. Alfabeta. Bandung.

Kabiru, L. M., Bello, M., Kabir, J., Grande, L., \& Morabito, S. (2015). Detection of Pathogenic Escherichia coli In Samples Collected At An Abattoir In Zaria, Nigeria and at Different Points In The Surrounding Environment. International Journal of Environmental Research and Public Health, 12 (1), 679-691.

Kusumayanti, H., Astuti, W., \& Broto, W. (2011). Inovasi Pembuatan Abon Ikan sebagai Salah Satu Teknologi Pengawetan Ikan. Gema Teknologi, 16 (3), 119-121.

Maskur, M. (2018). Pengaruh Waktu dan Suhu Sterilisasi terhadap Kandungan Proksimat Ikan
Bandeng (Chanos Chanos) Kaleng. Jurnal Airaha, VII (1), 17-29.

Mustar. (2013). Studi Pembuatan Abon Ikan Gabus (Ophiocephalus striatus) sebagai Makanan Suplemen (Food Suplement). Skripsi. Fakultas Pertanian, Universitas Hasanuddin. Makassar. Nugraheni, R. (2010). Laporan Magang di Bagian Pengujian Mikrobiologi Balai Besar Pengawas Obat Dan Makanan (BBPOM). Laporan Akhir. Program Studi Teknologi Hasil Pertanian, Fakultas Pertanian, Universitas Sebelas Maret. Surakarta.

Peng, S., Chen, C., Shi, Z., \& Wang, L. (2013). Amino Acid and Fatty Acid Composition of the Muscle Tissue of Yellowfin Tuna (Thunnus albacares) and Bigeye Tuna (Thunnus obesus). Journal of Food and Nutrition Research, 1(4), 4245.

Rahayu, W.P., Ma'oen, S., Suliantari, \& Fardiaz, S. (1992). Teknologi Fermentasi Produk Perikanan. Bogor: PAU Pangan dan Gizi.

Restu. (2016). Pengolahan Abon Ikan Karandang (Channa pleurophthalmus) dengan Penambahan Kelapa Parut. Ilmu Hewani Tropika, 5(1), 22-26.

Riansyah, A., Supriadi, A., \& Nopianti, R. (2013). Pengarun Perbedaan Suhu dan Waktu Pengeringan terhadap Karakteristik Ikan Asin Sepat Siam (Trichogaster pectoralis) dengan Menggunakan Oven. Fishtech, 2 (1), 53-68.

Sahara, R., Isamu, K. T., \& Ibrahim, M. N. (2018). Komposisi Gizi Abon Ikan Cakalang (Katsuwonus pelamis) 
dari Proses Pengawetan yang Berbeda. JFP, 1(1), 8-16.

[BSN] Badan Standardisasi Nasional. (1992). SNI. 01-2891-1992 Cara Uji Makanan dan Minuman. Jakarta: Badan Standardisasi Nasional. (2006). SNI. O12331.1-2006 Cara Uji Mikrobiologi Bagian 1: Penentuan coliform dan Escherichia coli pada Produk Perikanan. Jakarta: Badan Standardisasi Nasional.

(2013). SNI.

7690.1:2013 Abon Ikan - Bagian 1: Spesifikasi. Jakarta: Badan Standardisasi Nasional.

Suardana, I. W., Putri, P. J. R. A., \& Besung, I. N. K. (2016). Isolasi dan Identifikasi Escherichia coli O157 : H7 pada Feses Sapi di Kecamatan Petang, Kabupaten Badung-bali. Buletin Veteriner Udayana, 8(1),
30-35.

Sulthoniyah, S. T. M., Sulistiyati, T. D., \& Suprayitno, E. (2013). Pengaruh Suhu Pengukusan terhadap Kandungan Gizi dan Organoleptik Abon Ikan Gabus (Ophiocephalus striatus). THPi Student Journal, 1 (1): 33-45.

Takeuchi, T. (1988). Laboratory work, chemical evaluation of dietary nutrition. P 179-229. In: Watanabe T (ed). Fish mutrition and maricultur. Tokyo (JP): Kanagawa International Fisheries Training Center.

Winarno, F. G. (1997). Kimia Pangan dan Gizi. Gramedia Pustaka Utama. Jakarta.

Zuhra, Sofyana, \& Erlina, C. (2012). Pengaruh Kondisi Operasi Alat Pengering Semprot Terhadap Kualitas Susu Bubuk Jagung. Rekayasa Kimia dan Lingkungan, 9(1), 36-44. 